\title{
家畜・家禽のマイコトキシコージス
}

\author{
足立吉數 \\ 茨城大学農学部動物保健衛生学研究室 \\ (300-0393 茨城県稲敷郡阿見町中央 3-21-1) \\ キーワード : マイコトキシン中毒，飼料，家畜，家禽
}

(Received: October 16, 2002)

動物のマイコトキシンによる疾病は古くから知られている .このマイコトキシンは家畜・家禽及 び人に樣々な障害を与える化合物の総称である .このマイコトキシンのグループ分けは産生するカ ビの種類, 障害作用の種類, 障害の標的藏器, 兴の化学構造によって行われる.あるカビが産生す るマイコトキシンの種類は一種類とは限らないこと, 同じマイコトキシンが属の異なる複数の属及 び種によって産生される場合があるので, 産生するカビによる分類は複雑である．障害作用もしく は標的藏器による分類は良く知られている，例えば, 肝臓毒にはアフラトキシン, ステリグマトシ スチン , などがある . 腎藏毒としてはオクラトキシンなど, 神経毒としては麦角アルカロイド , フ モニシン, ボミトキシンなどがある．繁殖毒としてはゼアレノンが知られている．これらマイコト キシンによる家畜・家禽の中毒について, 濃厚飼料が問題になるマイコトキシンと, 粗飼料が問題 となるマイコトキシンか認められる . 飼料のマイコトキシン污染によって発生した有名な事故は, $\ulcorner$ 七面鳥のX病」として知られ，10万羽以上の規模で大量死が起こった事例がある．これによって アフラトキシンが発見された . しかし，このアフラトキシンによる家畜・家禽の中毒の報告事例が 比較的少ない．これは,マイコトキシンの診断の難しさが原因と思われる.表 1 - A 及びBには家 畜家禽に発生する一般的力ビ毒中毒について示した . 家畜の場合 , まず臨床症状で診断するわけで あるが他の原因を排除することが必要となる．仮に，マイコトキシン中毒が疑われても光の飼料へ のマイコトキシンの污染が確認されなくてはならない. しかし, 弚れらの飼料には必ずしも 1 種類 のカビが生えていたわけではない . また，一種類のカビで 2 種類以上のマイコトキシンが産生され る可能性がある.従って, 複数のマイコトキシンを摂取していた家畜に生じる影響, 障害作用は複 杂隹で, 診断が困難となる.これまで, われわれが経験した家畜・家禽のマイコトキシン中毒につい て以下に示した .

(1)乳牛のマイコトキシン中毒で食欲不振, 食滞を示し, 重症例は死亡.9 頭が発症, 2 頭が死 亡 , 一頭が廃用 . 剖検で腹水を認めるも肝細胞傷害がなかった . 飼料からの抽出物中にアフラトキ シンとステリグマトシスチンが含まれ，光れのマウスへの腹腔内投与によってマウスは死亡した . この場合, 酵素免疫測定法でアフラトキシンを確認. (2)産卵彩 3000 羽のうち 20 羽の肛門付近に出 血の痂皮がみられ, 肝藏の出血, 脂肪肝が見られる症例で, 飼料から Aspergillus flavusが分離され またアフラトキシン $B_{1}$ も検出された . しかし , 直接的原因がアフラトキシンであるか不明 . (3)豚 の腎藏障害が疑われその血漿からオクラトキシンA を確認 . 3 フッ化ボロンによるオクラトキシン のエステル化によって確認 . (4)養鶏場で無作為に採取された䳕血墏からアフラトキシン $\mathrm{B}_{1}$ を検 出. 光の飼料から高濃度のアフラトキシン $\mathrm{B}_{1}$ を検出 . 症状はなし . (5)動物園で飼われていたペン 


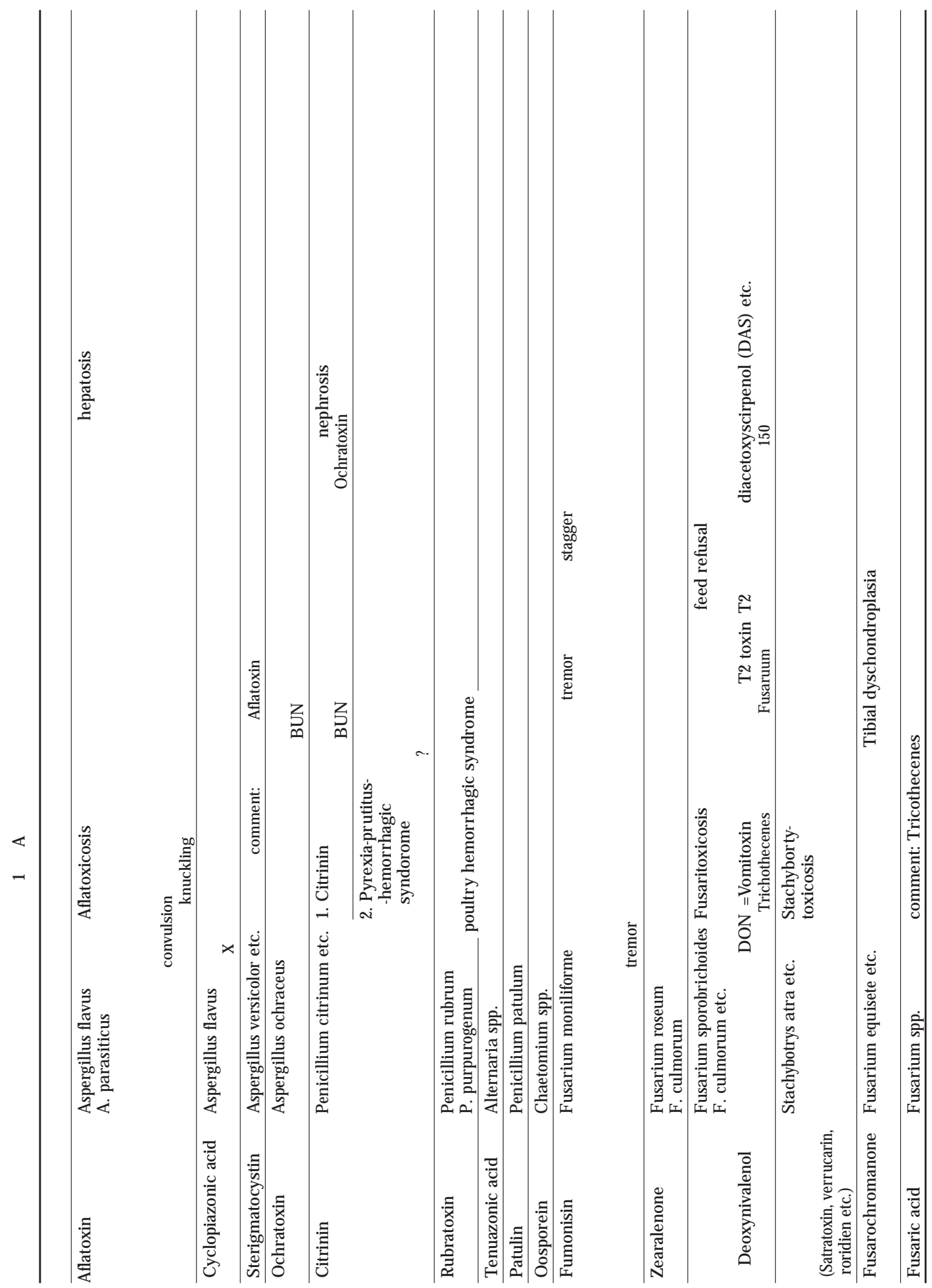




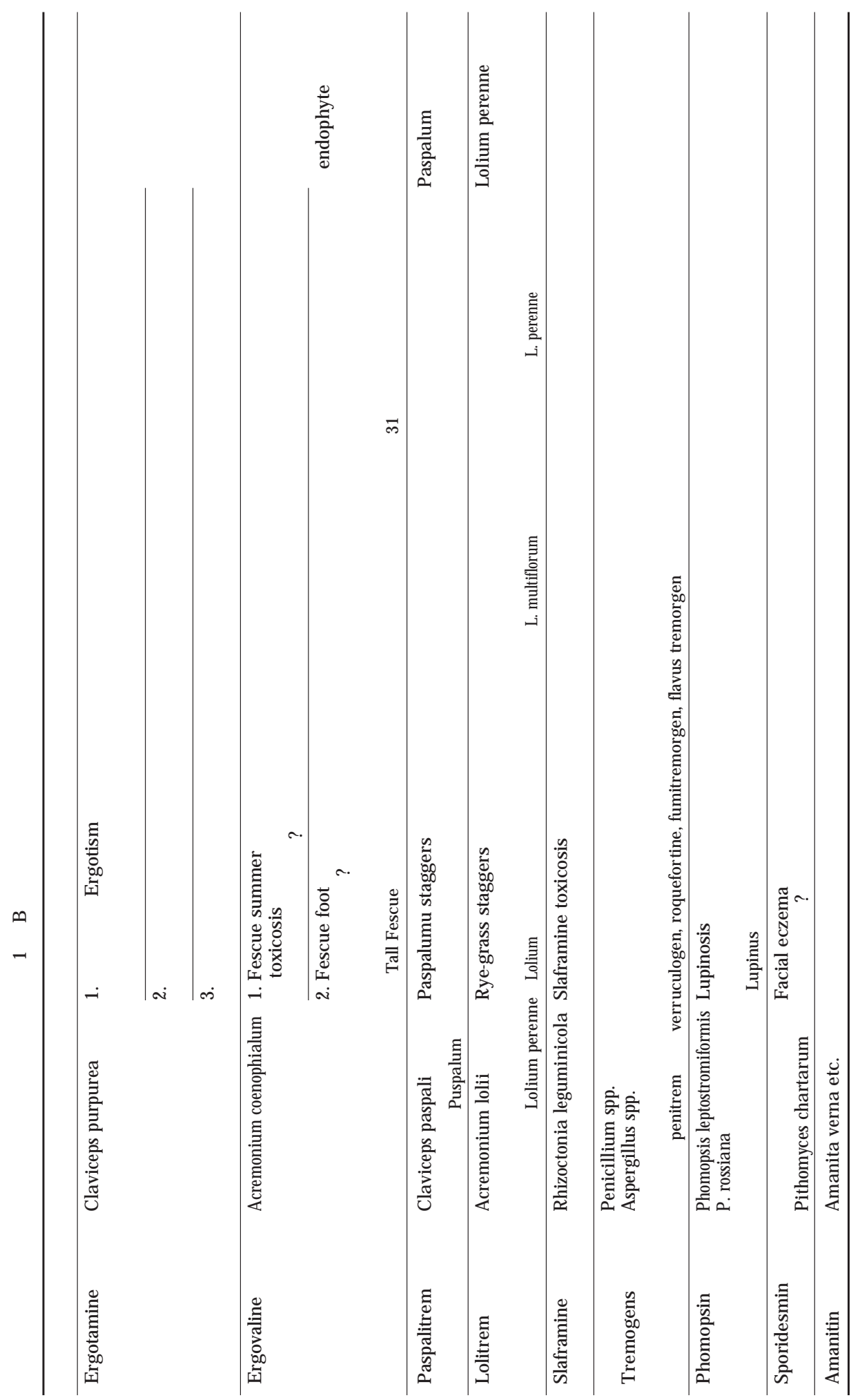


ギンの死亡例の藏器から Aspergillus flavus が分離されアフラトキシンを産生していることが確認さ れた . (6)西南暖地において鶏 (地鶏) の腹水症多発 . 飼育羽数の $5 \%$ に達するが原因つかめず，マ イコトキシンの污染が疑われている.このようにわが国において顕著な発生ではないがマイコトキ シン污染が疑われる症例がぽつぽつ見られることは今後,更なる調査を必要とするのかもしれない . 特に, 温暖化に伴い年平均気温 $16^{\circ} \mathrm{C}$ の地域が徐々に拡大していることによるマイコトキシコージス の発生数の増加が危惧される .

\section{Mycotoxicosis in domestic animals and poultry}

Yoshikazu AdACHI: School of Agriculture, Ibaraki University (3-21-1 Chuo, Ami-machi, Inashiki-gun, Ibaraki-ken 300-0393, J apan)

In Japan, the outbreak of mycotoxicosis in cattle and poultry is not many in number. However, annual mean of the temperature in Japan is still increasing and the risk of animals exposed by mycotoxin may increase. We have been investigating the mycotoxicosis in cattle and poultry and we could show six cases of mycotoxicosis which were suspected in this report. In case 1, incidence of cattle affected with afltoxicosis were shown and afltoxin and sterigmatocystin were detected in feed. In case 2, incidence of chicks affected with aflatoxin and the detection of aflatoxin $B_{1}$ were shown. In case 3 , swine nephritis induced by ochratoxin was shown. In case 4 , the detection of aflatoxin $B_{1}$ in blood of chicks and the feed was shown. In case 5 , isolation of Aspergillus flavus in penguin was reported. In case 6, ascites of chicks in south district in Kyushu Island was shown and incidences by mycotoxins were suspected. In general, diagnosis of mycotoxicosis is complicate because many other diseases must be negative and mycotoxins should be detected in feed and organs in the affected animals.

Key words: mycotoxicosis, feed, domestic animal, poultry 